\title{
The Application of Multiple Intelligences in Islamic Religious Education
}

\author{
Ucup Supriatna', Zulvia Trinova², Samuel PD Anantadjaya3, Mariana Puspa \\ Dew4, irma M Nawangwulan5
}

DOI: $10.35445 /$ alishlah.v13i3.700

\begin{tabular}{l}
\hline Article Info \\
\hline Keywords: \\
Islamic Education; \\
Application; \\
Multiple Intelligences
\end{tabular}

Kata kunci:

Pendidikan Agama;

Penerapan;

Kecerdasan Ganda

\begin{abstract}
This qualitative research aims to determine how crucial Multiple Intelligence is in Islamic religious learning. The method in this research is a theoretical study that tries to find hypotheses by examining various research sources and online media about Multiple Intelligence. The collecting data is by gathering some literature obtained from various articles, both accredited national journals and reputable international journals. Data analysis is done by mapping from the collected data and obtaining literature from multiple intelligences in Islamic Religious Education. The result of this research is that with the application of multiple intelligences, the teacher can map the condition of students based on their potential and interests and with the among system, the characteristics of students can be continuously fostered without being shackled to their "independence" to develop.
\end{abstract}

\begin{abstract}
Abstrak
Penelitian ini adalah penelitian kualitatif yang bertujuan untuk mengetahui seberapa penting Multiple Intelligence dalam pembelajaran agama Islam. Metode dalam Penelitian ini adalah Kajian teoritis ini mencoba menemukan hipotesis dengan menelaah berbagai sumber penelitian dan media online tentang Multiple Intelligence. Teknik dalam mengumpulkan data dengan cara mengumpulkan beberapa literature yang didapat dari berbagai artikel baik jurnal Nasional terakreditasi maupun jurnal international bereputasi. Analisis data dengan cara melakukan pemetaan dari data yang terkumpul dan didapatlah beberapa literature yang sesuai dengan multiple intelligences di dalam Pendidikan Agama Islam. Hasil dari penelitian ini adalah dengan penerapan multiple intelligences guru dapat memetakan kondisi siswa berdasarkan potensi dan minatnya serta Dengan sistem among, karakteristik peserta didik dapat terus dibina tanpa terbelenggu "kemandiriannya" untuk berkembang.
\end{abstract}

${ }^{1}$ STAI Al-Haudl Ketapang, Ketapang, Kalimantan Barat, Indonesia

Email: kangucuptea@gmail.com

${ }_{2}$ University Islam Negeri Imam Bonjol, Padang, Indonesia

Email: zulviatrinovagogb@gmail.com

3 International Univ Liaison Indonesia, Tangerang, Indonesia

Email: spdanantadjaya@gmail.com

4 Institut Teknologi dan Bisnis Asia Malang, Malang, Indonesia

Email: marianapuspadewi@gmail.com

5 International Univ Liaison Indonesia, Tangerang, Indonesia

Email: mnwulan@gmail.com

Vol.13 (3) December, 2021

Received: June 24, 2021; Received in revised form: November 2, 2021; Accepted: November 28, 2021; Available online: December 30 , 2021. This is an open access article under a Creative Commons Attribution-NonCommercial-ShareAlike 4.o International License. 


\section{INTRODUCTION}

Developing students' potential is necessary to achieve success in achieving education and success in attaining learning. The government, in this case, the Ministry of Religious Affairs, has compiled an educational curriculum both from the level of Madrasah Ibtidaiyah (MI), Madrasah Tsanawiyah (MTS), and Madrasah Aliyah (MA). The curriculum has been developed Character Education, Attitudes, Abilities and individual skills (Irsad 2016; Nurmaidah 2014; Wafi 2017). Education as an art is a mandatory education that runs by the character and desires of everyone(Wibawa 2017). Each other has different characters. This is where teachers should understand them in a certain way. As a result, all students can practice efficiently. Learning applications are intended to measure skills, increase student potential, and make students independent. Therefore, learning should actively connect students because they essentially practice. At the same time, the teacher's presence serves more as a facilitator. In this case, the procedure of applying learning methods becomes very meaningful.

The explanation of character education is a conscious effort made by families, communities. Following the government through teaching guidance and exercises in schools and outside schools throughout life to prepare students to develop the potential that exists in themselves following the national education legal system of 2003(National 2003). The excellent quality of resources can be seen from the attitudes and behaviours of students. Can form the character and attitude of students can shape the character and attitude of students by providing direction and shaping to carry out the following expectations(Hasibuan, Shah, and Marzuki 2018; Key and Setiawan 2013; Key and Winarni 2013; Sudrajat 2011). National education aims to have a just and prosperous, intelligent society to advance the nation. Achieving this requires a struggle.

Islamic learning in schools directs different lessons that include several subjects that students must learn, let alone a student master or permeate the lessons submitted by the teacher(Nasir 2020; Sawaluddin 2018). This is not easy because a student certainly has a different level of intelligence. After all, a person is born in clean, holy or fit conditions and has certain characteristics and talents that can develop over time. Based on Islamic Religious Learning, educational interaction forms a way of practising and guiding activities carried out by teachers and all students in the forum category (Irsad, 2016). The category is where a teacher interacts with all his students, and the teacher shares good positions and illustrations for his students.

Teachers who do not understand student intelligence must be different from teachers who master the intelligence of teaching participants. Of course, teachers who do not master want difficulty providing activities to develop their abilities or abilities. Intelligence rises to a very prominent place in the foundation of learning, but some teachers partially understand it (Hirst 2006). The intelligence of a student is diverse and not just one but also diverse. It is not easy to master the intelligence of students one by one. The problem needs to be addressed through learning strategies that follow the accuracy of the intelligence of teaching participants because students must be in elementary school to permeate, pursue and master the contents of the lesson modules taught following intelligence or the ability to follow the students themselves(Istiningsih and Nisa 2015). For the diverse philosophy of Intelligence, everyone has eight different intelligence bits and then grows into nine different parts of Intelligence. By acknowledging that Intelligence means a teacher understands the unequal character in each of his students. Teachers should think about and prepare for learning activities through characters similar to students' intelligence skills well (Amir Hamzah 2009). Therefore, they want to directly affect learning or the ease with which students respond and freeze the stewardship found them. Therefore, mastering the design of Multiple Intelligences is a diverse intelligence that one has. Teachers want it easier to recognize whether Intelligence is an ability in learners. Among the intelligence is 1) oral or linguistic intelligence; 2) logic-mathematical intelligence; 3) visual-spatial intelligence; 4) musical intelligence; 5) intrapersonal intelligence; 6) Interpersonal intelligence; 7) kinesthetic intelligence or body; 8) naturalist intelligence; and 9) existentialist intelligence(Istiningsih and Nisa 2015; Qadariyah 2019; Tastin, Ibrahim, and Fitri 
2018). In Multiple Intelligences, teachers who learn Islam can recognize that one student is unlike any other student. There are several bits of intelligence where each student/student certainly has one important intelligence in Multiple Intelligences. If the Student Intelligence does not grow by the teacher until Intelligence do not grow to its full potential(Amir 2013).

Several previous studies discussing intelligence have been conducted, such as research conducted by (Suniyah, Rohmadi, and Sulistiyo 2018) with the title Of Double Intelligence-Based Writing Learning Implementation Strategy. This research resulted in a multi-intelligence based learning process at PSM Magetan International Islamic Elementary School that went well in the application of Multiple Intelligence Research. Teachers integrate various methods with dual intelligence in writing with authentic judgment. Other studies have also been conducted (Makrufi and Prihatno 2020) under the Dual Intelligence Dimensions in Indonesian Religious Education. The results show that the dual intelligence dimensions in the PAI 2013 curriculum at the Elementary School level can be seen by classifying nine bits of intelligence (according to Howard Gardner) in each of the core competencies. Spiritual competence contains existential intelligence. Social competence is related to personal and intrapersonal intelligence. Aspects of knowledge include logical-mathematical intelligence, linguistic intelligence, musical intelligence. Meanwhile, competency skills contain visual-spatial intelligence, kinesthesis intelligence, and naturalist intelligence. Other research has also been conducted by (Itqon 2021) under the title Of Implications of Humanistic Theory and Dual Intelligence in the Development of Islamic Educational Learning. The results of this study are learning processes that are considered effective if students understand themselves and their environment. Students in the learning series must be bound so that sooner or later, they can actualize themselves as best they can. Another study was also conducted by (Nuraini, Helandri, and Arikarani 2020))about Dual Intelligence Effect on PAI Subject Fiqh Material on Student Learning Outcomes. The result of this study is that a dual intelligence strategy affects student learning outcomes in Islamic Religious Education subjects. Of the several pieces of literatures that make references to this article, no one discusses the condition of students based on their potential and interests. This article aims to explain and map students' potential among the system. That and the system among. Such mapping is important because it will know students' potentialandinterests with among systems. Success in the application of multiple intelligence depends on among.

\section{METHODS}

This study uses literature review research which literature review by finding some sources relevant to articles related to the way research data is collected by searching for articles contained in nationally accredited journals online and collecting from several repositories through google scholar database, Garuda Portal, Directory of Open Access Journals and national library (Wee \& Banister, 2016). A literature review uses literature published in $2010-2021$ to access the full text in pdf and scholarly format (peer-review journal). The journal's criteria reviewed are articles in Indonesian and English research journals. Articles that fit the criteria for inclusion and exclusion are taken for further analysis. 


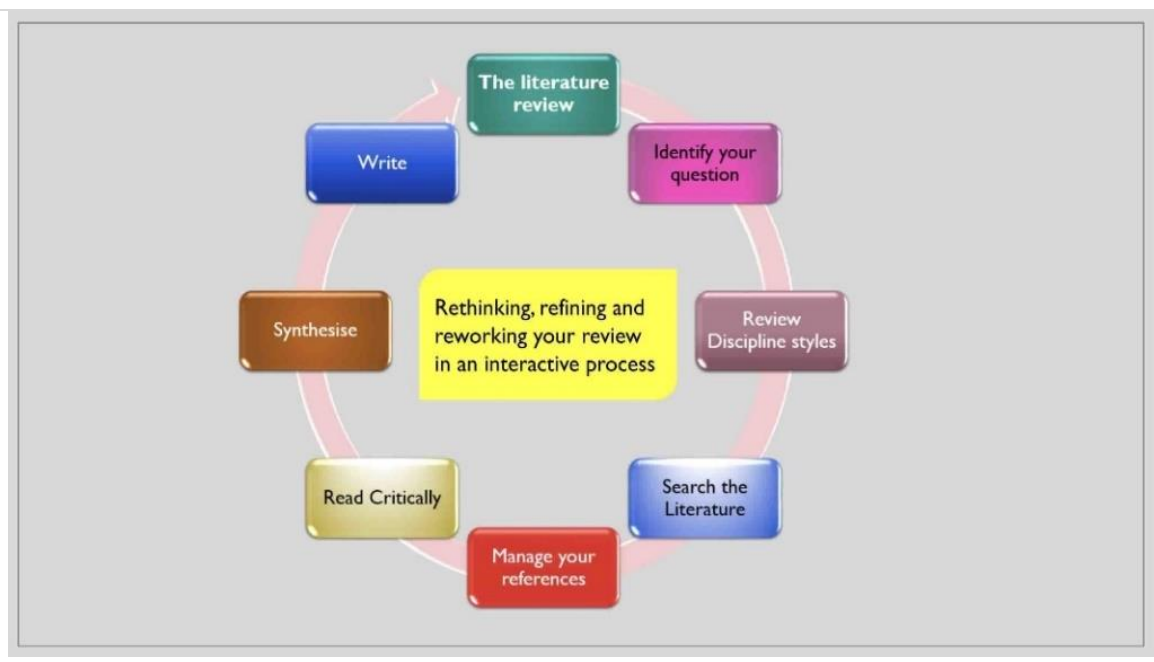

Figure 1. Literature Review Method Process

\section{FINDINGS AND DISCUSSION}

Method learning is a method so that teachers in obtaining results that match the purpose of learning is to try to master the skills of students and master the character of students by replacing the best-selling actions related to the science of insight, skills of students and the actions of students or all views of the character. To achieve various intelligence developments of students, they must try learning as efficiently as possible and be valuable and productive. The atmosphere of learning is packed with an exciting atmosphere.

Intelligentsia Multiple Applications by outline have some programming levels, methods, and assessments. The early step that needs to be implemented is to monitor students' attitudes both within and outside the category. The urgency of Multiple Intelligences in Islamic Religious Learning is learning that produces a foundation of insight and Intelligence for teaching children. In Islamic religious learning, children recognize the basics of reading, writing, and counting. In Islamic Learning, teachers also recognize the ability to win that has been possessed by teaching children. Here, teachers must describe that each student is intelligent and has plural intelligence even in different subjects.

Gardner expressed at least nine types of Intelligence: Linguistic Intelligence; Mathematical Intelligence makes sense; Spatial Intelligence; Musical Intelligence (tone accent), Kinesthesis-body intelligence; Interpersonal Intelligence (in person), interpersonal Intelligence (intrapersonal), naturalist intelligence (area), and existential Intelligence (González-Treviño et al., 2020)(Figure 2)

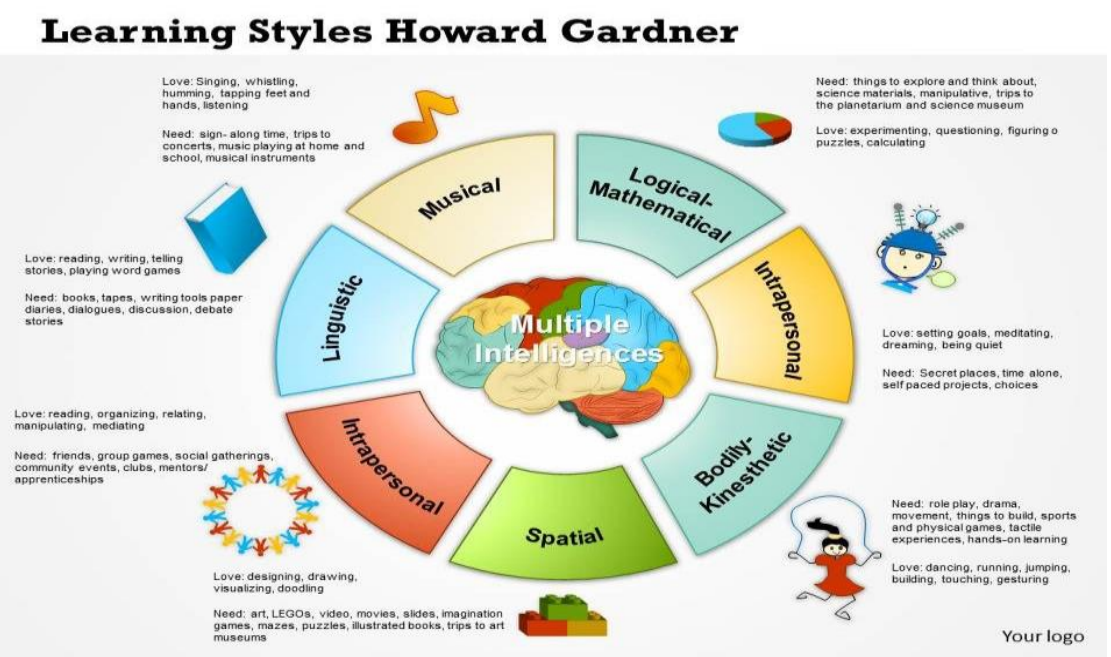

Figure 2. Multiple Intelligence Howard Gardner 
Each student has all the types of Intelligence above, and there is only some more growing intelligence than others. However, it can ultimately raise all Intelligence. That is in line with the opinion of Asri Budiningsih, who said that: (1) each group has all the Intelligence; (2) many people can increase each Intelligence to the maximum level; (3)Intelligence generally works together with unique methods; and(4) there are many methods to make it bright. Dedication to the existence of comparisons in each student/student as a form of this person might create a brand of more minor bright youngsters. Meanwhile, there is not one child born less intelligent. The child has not created a suitable teacher for himself. The motivation given is to influence the progress of each child's essential abilities significantly.

This is often found in schools, and teachers share three intelligence circles with their students. The early ones were for great mathematical Intelligence and had great Intelligence Quotient (IQ) results. Intelligent children often spoke to these early people. The second class has intelligence quotient (IQ) results and mathematical intelligence skills that are not very large and moderate. These people are often spoken to by children who are ordinary and moderate. On the contrary, the third classes have intelligence quotient (IQ) results and small sensible mathematical intelligence skills. They are named as children who are less intelligent and unable. This grouping is unusually wrong and does not respect the characteristics found in children.

The inspiration that Stenberg also put forward in 1985 was in his philosophy of Intelligence. One method to initiate inspiration gained from the philosophy of plural Intelligence is to design training activities with assessments that focus on different bits of Intelligence initially and let students sort out the training activities and assessments sourced to the resources they have each. Multiple Intelligence platform learning needs to be implemented in learning in essential learning. That is because Islamic Learning is the basis in the learning stage. The learning that is tried in Islamic Religious Learning is used as a child's practice to increase their knowledge in a more significant way of learning. As a result, if the child's intelligence neglect has been tried, essential learning until the child cannot grow in a maximum way matches the child's ability attention. On the contrary, it continues to be the early development of Intelligence possessed by the child raised, continues to be a flash also teachers recognize the abilities possessed by the teaching child.

Teacher competence in ensuring the characteristics of children is needed to describe the skills possessed by students and used as a reference in sharing improvements in learning. Can observe the characteristics of this child through various ends of vision, can be observed through Early, Ordinary intelligence quotient (IQ), its role in Multiple Intelligence. Regular intelligence measurement and multi-intelligences monitoring need to be tried at the beginning of the child's entry into school. This subject refers to describing the skills and attention possessed by students and is used to share improvements that are suitable with the child's wishes in a particular way. Second, attention practice. After carrying out multiple monitoring intelligence that the teaching child has owned, we want to recognize the child's learning of training. These attention teachers are more positioned to provide the desire needed by students in the way of learning that is matched with the child's attention; Third, Enthusiastic practice. Enthusiastically practising children also need to be observed as the determination of treatment among system to be handed over to the child using people; fourth, enthusiastically exploring mentoring; fifth, quality of interaction; and sixth, quality of health.

\section{Multiple Intelligences in the Context of Islamic Religious Education}

The world of education, especially Islamic Studies, must address these multiple intelligences in various ways of learning. This subject means a teacher's attention in facilitating various desires possessed by the teaching child. Can form multiple intelligences based on ability, social, and religion that can be raised with contextual learning. The concrete illustration is to be someone with a member power; he must have good social skills and good religion. As a result, it is fair to say that social and religious factors trump talent. With that integration, until the progress of the ability does not become dry, this is what is expected in the nation's life. Good social and religious Intelligence in everyone 
wants to make citizens, and make social and religious is a learning effort. Learning is a way of changing each person's attitude that is expected in the way of learning. The effort that can be tried by learning is through the curriculum implemented in schools by teachers.

The initial method of multiple intelligences application is to implement the verticalization of Intelligence Quotient (IQ) implementation of Multiple Intelligences and monitor multiple intelligences owned by the teaching child. This subject is trying to recognize the shrinking down skills as well as the unique skills that have. Second, based on the results of intelligence quotient (IQ) test and monitoring skills and other forms of tests that have been owned, do the creation of training groups because of helping training mentoring and assessment of ways through monitoring. Third, give attention to the child in his group. Do not look at children in all categories. Teachers can do learning, mentoring, and way assessment.

The methods for child training assistance are based on each: (1) Stay away from teachers exercising will. The teacher is a provider in the way of learning. As a result, the child only provides everything needed because the real one is the teaching child, not the teacher. As a result, do not demand students/students poll the teacher's will because not always the teacher's will be good for the child. It can be by exploring the will of the child's teacher so that they run out of enthusiasm and curiosity in practising and while looking at the subject of practice that the child again learns. Allow the child to work according to his ambitions to respond independently to the dilemmas contained in the subjects he is studying. (2) Focus attention assistance on the characteristics of the child. Teachers are always obliged to share their attention with each child. must know (3) characteristics of children must know ( 3) Characteristics of children as early as possible. (4) Accuracy assistance needs to observe the alliteration of talent, expertise, enthusiasm, and others.

The among system mentoring plan is one of the training assistances plans by looking at the smarts of various children. Among system is a learning method taught by Ki Hajar Dewantara, which requires the protectors to explore and prioritize the individual nature of students by not carrying out the influences that surround it. Can implement differentiated learning to provide children in the way of learning. Differentiated learning is a way of learning that is formed from a perspective and a significant commitment in familiarizing the curriculum, guiding strategies, evaluation strategies, and category areas with the wishes of all teaching children. 15 This differentiated Learning is not at all contrary to the equality plan in the metaphysical study design. Pring suggests that equality in the design of learning metaphysics means that each child has a similar opportunity to get learning regardless of category or economic status, or wealth.

Differentiated learning responds to the anxiety of some teachers who feel legally unbalanced while disguising aspects of content, ways, and products that associate students who are different good in terms of readiness, attention, or learning style. When a student whose learning achievements are far from expected, the factor must not be because this child is less intelligent. The alarm teacher must match well between the content, ways successfully, and products with readiness, attention, and teaching style. Teachers should be able to make changes to the content, ways, and products matched to the wishes of each teaching child, not homogenize them.

\section{Differentiated Learning Methods in The Classroom}

In the usual way, differentiated learning is a way of practicing guiding focusing on the child, not on the teacher. On the contrary, in the conventional category, the teacher leads the category. Students learn to watch the teacher deliver the lesson module, take note of it. After that do exercises for the teacher. In differentiated learning, teachers must be competent to adapt their interference routines in conventional categories, with all students' wishes throughout the learning. Teachers give opportunities to all students to improve their skills to dismantle their case and organize their own time in the application of tasks. Suppose the teacher can try this matter until students work more productively. There is also a reflection in a particular way of learning differentiated by Arends and Kilcher. 
Initially, it should start with implementing good programming. In designing differentiated learning, teachers should consider classifying modules or content, diagnosing the teaching children's readiness, and designing various jar defence experiences. This subject means that the learning that is tried can accommodate all students with their desires and circumstances. Second, teachers began to organize differentiated categories. The setting of this differentiated category must be based on the comparison found in each teaching child. At one duration, students may carry out training activities uniquely. However, in other durations, students can also carry out training activities in a teamed manner. Group arrangements in this differentiated category are tried flexibly, can be based on the suitability of attention, academic readiness, or the style of training of the teaching child. Third, teachers are also expected to draft evaluations that fit in differentiated categories. Evaluation in different categories is different from evaluation in conventional categories in general. $\mathrm{He}$ is a relentless evaluation and is a structured part of learning. In other words, the evaluation was tried early, formative, and summative. Not a kind in the conventional category that applies evaluation only at the end of learning and implements it separately using learning. Moreover, in differentiated Learning, Students can sort out the type of evaluation they want or match their attention, readiness, and training style.

On differentiated learning, reviewing programming, setting up, and implementing Multiple Intelligences evaluation alone is not enough. What kind of position students and teachers in differentiated learning is also a matter that means to be reviewed? In differentiated learning, teachers serve as providers for children who have power over an active, safe, exciting way of practising. In differentiated learning, students become learning centres. Therefore, what students want to learn and how students want to learn should estimate the wishes of all teaching children. That is, curriculum creation, strategic determination, and others similarly should think about all the wishes of the teaching child.

Regarding other meanings that must observe in differentiating categories is to make optimistic assumptions students to the teacher and vice-reverse, teacher to the teaching child. Teachers should have an optimistic assumption towards all their students in the differentiating category. Students who assume that the teacher offers warmth, income, and appreciation for themselves should easily assume that he is able academically and has a sense of belonging to his school. Thus, the feeling that he is treated warmly, well obtained, and judged by all his advantages and disadvantages will arise in the assumption of the teaching child.

\section{Strategies in Differentiated Learning}

from Arends and Kilcher, they can raise some strategies in learning differentiation. First, teachers can raise the profile of the teaching child. In a small category, the teacher prepares the student's profile. On the contrary, teachers' cooperation and teaching children make students' profiles in significant categories. Q\&A, monitoring, checklist, and surveys are instruments that can use to calculate in form and the profile data of the teaching child. Second, share modules with different shapes and with different levels of distress. Un subdued early value means producing categories differentiation be collect materials with different levels of distress on a specific point are sourced to the curriculum. Teachers can serve in teams for duration efficiency. At least four levels of modules must be present for one point to be submitted. Third, look at different cognitive ways. Cognitive regions that are interpreted to be broken down into six levels assume that are organized from the very simple to the very environmental are: recognize, master, apply, analyze, synthesize, as well as assessing. Cognitive processing formats cover categories next: remembering, mastering, applying, analyzing, assessing, and creating. This cognitive way is also organized from very simple to very environmental. Fourth, share options in practice and evaluation activities. Share options in training activities and student evaluation make students practice according to their attention and ability. Option opportunities include library options, research points, PR options, category activities, writing strategies, research procedures, information-making forms, and evaluation strategies. Can 
develop some assessments based on the options of practising activities. Fifth, carry out flexible grouping and categorization of small groups. Students want the opportunity to serve alone, with a companion, in a small group, or a category by way of totality. Flexible groups can be arranged randomly using some benchmarks or prepared with a specific purpose based on ability, attention, and readiness. Sixth, use a practice contract. A training contract is a recorded agreement between a teacher and a student who can guide free tasks. This contract fits the purpose of each day and weekly activities, duration, base, and product obtained. Lsi, practice strategies, and products made various suitable attention and skills of the teaching child. Meetings( weekly or two weekly) try to share the victims back and discuss teaching children. Seventh, implementing curriculum compaction. Compaction of curriculum intended for students who can teach more lightning( Advanced student). After completing the curriculum goals, teachers enrich them with various more challenging current subjects, such as the latest modules or skills. Eighth, conducting teachers of the same age and using mentors and experts. Can use teachers of the class to help students who are complex in mastering a basic plan or a couple of students/students can be similarly tasked to prepare a test or split share the victim back in an obligation. In the usual way, Supervisor means a student or an older person who shares learning and education with younger or unprofessional students. Experts are those who understand modules as well as professionals in specific matters. Students located at the level can further connect with them through the seminar, nursery learning, and similar. Ninth, observe intelligence plural. Every student is competent, even indifferent matter and they have Intelligence. Look Intelligence these are other strategies that can support Learning differentiation. Gardner( in Arends and Kilcher) says that there are at least eight types or types of Intelligence: logicalmathematical, linguistic, musical, spatial, kinesthetic, interpersonal, intrapersonal, and naturalist.

Everyone has all these types of Intelligence. It's just that there is some Intelligence that is more growing than others. However, it can wholly raise all Intelligence. One method of starting inspiration from the philosophy of plural Intelligence is to design training activities with assessments that focus on different bits of Intelligence initially and let students sort out the practice activities and assessments sourced to the resources they have each. Tenth, think about the style of practice as well as the options of the teaching child. What kind of learning do we design based on intelligence comparisons, such as designing learning based on the teaching child's style of practice and options? For example, the teacher can make some lessons that are matched with children with the style of oral and auditory practice. Some are matched to help children with the style of visual practice. Eleventh, learn cubing. Cubing is a strategy raised by Cowan and Cowan (in Arends and Kilcher, 2010) to expose students to perspectives and methods of assuming different points. The 6-part dice outline additional guidance, obligations, and types of issues in this strategy. Each part of the dice replaces the form of 6 cognitive obligations put forward by Bloom. So, each section provides challenges for students to remember, master, practice, analyze, consider, and produce twelfth, organizing categories that focus on practice and focus on attention. Setting up a training centre and a mint centre is another method of providing a different learning path. Thirteenth, using cooperative learning strategy and problems-based learning. Zigsaw's cooperative learning strategy, group analytics) can be used to share differentiated training opportunities for teaching children. The Dilemma of Base Learning, a small group, can also be used for this matter. Fourteenth, drafting the tasks in a row. Tiered obligations consist of various obligations or training activities in varying fatigue levels but have similar problems or standards.

Multiple Intelligences in Nation Building Mastering and applying multiple intelligences in learning is a way of learning that humanizes people. By mastering the subject, students feel treated similarly to each other. With the fulfilment of students' wishes personally, students can grow to match their abilities and intelligence. Must integrate Learning with the attention and desire of the child. With such integration, until the progress of the ability does not become dry, this is what is expected in the nation's life. Good social and religious Intelligence in everyone wants to make citizens, and make social and religious is a learning effort. Learning is a way of changing each 
person's attitude that is expected in learning. Thus, learning has applied the Learning of Bhinneka TunggalIka, which became the Cogan of Indonesian society, into the way of learning. Thus, the child's soul is formed who matches his progress without any urges, persecutions, and other criminality. Thus, learning creates the nation's development through the comparison that is there. By recognizing the ability of the teaching child and sharing services that match his circumstances, the country can be expected (read: Indonesia) candidates as professional experts. The basis of energy experts is what will, in turn, become an asset of the State. Indonesia is ambitious to have professional maestros in various aspects when guided correctly.

\section{CONCLUSION}

Based on the explanation above, we can conclude that this can be done by mapping students' potential and interests. This method is very effective because it will show the potential students can develop and what interests them want. In learning will emerge the nature of student leadership. These properties will follow the concept of system-based learning and differentiation. If viewed from the perspective of human resources, this will make it an asset because students can grow different traits but still one or another name for the nature of diversity. In developing students' independence attitudes, students will be free to develop independent attitudes by applying the Among system. This has a good impact so that students are free to express themselves. The concept of thinking of Indonesian educators as applied by Indonesian educator Ki Hajar Dewantara can work well. This concept is very good because he wants students to be free or called independent in thinking, their hearts, and their work so that students can develop themselves as a whole. In this study, the application of Multiple Intelligences needs to be investigated further, and it is hoped that there will be further research in the application of Islamic religious education.

\section{REFERENCES}

Amir, A. (2013). Pembelajaran Matematika Dengan Menggunakan Kecerdasan Majemuk (Multiple Intelligences). Logaritma, I(01).

Amir Hamzah. (2009). Teori Multiple Intelligences Dan Implikasinya Terhadap Pengelolaan Pembelajaran. Pendidikan, 4, 251-261.

Arrasmith, D. G. (2006). Comprehension A Cognitive Learning Model. 1(19).

Bruns, W., \& Schäfer, K. (2004). Remote Control of Real and Virtual Welding Robots for Learning. IFAC Proceedings Volumes, 37(5), 215-219. https://doi.org/10.1016/s1474-6670(17)32369-8

González-Treviño, I. M., Núñez-Rocha, G. M., Valencia-Hernández, J. M., \& Arrona-Palacios, A. (2020). Assessment of multiple intelligences in elementary school students in Mexico: An exploratory study. Heliyon, 6(4). https://doi.org/10.1016/j.heliyon.2020.e03777

Hasibuan, A. A., Syah, D., \& Marzuki, M. (2018). Manajemen Pendidikan Karakter Di Sma. Tarbawi: Jurnal Keilmuan Manajemen Pendidikan, 191. https://doi.org/10.32678/tarbawi.v4io2.1230

Hirst, P. H. (2006). What is Teaching? Journal of Curriculum Studies, 3(1), 37-41. https://doi.org/10.1080/0022027710030102

Irsad, M. (2016). Pengembangan Kurikulum Pendidikan Agama Islam Di Madrasah (Studi Atas Pemikiran Muhaimin). 2(1), 230-268.

Istiningsih, \& Nisa, A. F. (2015). Implementasi Multiple Intelligences dalam Pendidikan Dasar. AlBidayah : Jurnal Pendidikan Dasar Islam, 7(2), 182-196.

Itqon, Z. (2021). Implikasi Teori Humanistik Dan Kecerdasan Ganda Dalam Pengembangan Pembelajaran PAI. Jurnal Pendidikan Islam, 7(1). https://doi.org/10.37286/ojs.v7i1.96

Kunci, K., \& Setiawan, D. (2013). Peran Pendidikan Karakter Dalam Mengembangkan Kecerdasan Moral. Jurnal Pendidikan Karakter, o(1), 53-63. https://doi.org/10.21831/jpk.voi1.1287

Kunci, K., \& Winarni, S. (2013). Integrasi Pendidikan Karakter Dalam Perkuliahan. Jurnal 
Pendidikan Karakter, o(1), 95-107. https://doi.org/10.21831/jpk.voi1.1291

Makrufi, A. D., \& Prihatno, M. R. A. B. (2020). The Multiple Intelligences Dimension In Indonesia`s Religious Education. Al-Hayat: Journal of Islamic Education, 4(2). https://doi.org/10.35723/ajie.v4i2.107

Nasional, U. S. P. (2003). Law Of The Republic Of Indonesia Number 20 Year 2003 Concerning National Education Systems. Acta Pædiatrica, 2O, 6-6. https://doi.org/10.1111/j.16512227.1982.tbo8455.x

Nasir, M. (2020). Curriculum Development and Accreditation Standards in the Traditional Islamic Schools in Indonesia. Journal of Curriculum Studies Research. https://doi.org/10.46303/jcsr.2020.3

Nuraini, N., Helandri, J., \& Arikarani, Y. (2020). Pengaruh Multiple Intelligences Pada Mata Pelajaran PAI Materi Fiqih Terhadap Hasil Belajar Siswa Kelas VIII SMPN Sumber Rejo Kabupaten Musi Rawas. Edification Journal, 2(2). https://doi.org/10.37092/ej.v1i2.138

Nurmaidah. (2014). Kurikulum Pendidikan Agama Islam. MA Jurnal Al-Afkar, 3(2), 41-54.

Qadariyah, L. (2019). Analisis Multiple Intelligences dalam Diri Anak Menurut Munif Chatib. Jurnal Kariman, 6(2). https://doi.org/10.52185/kariman.v6i2.93

Sawaluddin, S. (2018). Konsep Evaluasi Dalam Pembelajaran Pendidikan Islam. Jurnal Pendidikan Agama Islam Al-Thariqah, $3(1), \quad 39-52$. https://doi.org/10.25299/althariqah.2018.vol3(1).1775

Sudrajat, A. (2011). Mengapa Pendidikan Karakter. Jurnal Pendidikan Karakter, I(1). https://doi.org/10.21831/jpk.v1i1.1316

Suniyah, S., Rohmadi, M., \& Sulistiyo, E. T. (2018). Implementasi Strategi Pembelajaran Menulis Berbasis Multiple Intelligences. Sekolah Dasar: Kajian Teori Dan Praktik Pendidikan, 27(2). https://doi.org/10.17977/umoogv27i22018p174

Tastin, T., Ibrahim, I., \& Fitri, R. S. (2018). Implementasi Prinsip Multiple Intelligences Dalam Meningkatkan Hasil Belajar Siswa Pada Mata Pelajaran Bahasa Indonesia di MI Najahiyah Palembang. JIP: Jurnal Ilmiah PGMI, 3(2). https://doi.org/10.19109/jip.v3i2.1651

Wafi, A. (2017). Konsep Dasar Kurikulum Pendidikan Agama Islam. Edureligia; Jurnal Pendidikan Agama Islam, 1(2), 133-139. https://doi.org/10.33650/edureligia.v1i2.741

Wee, B. Van, \& Banister, D. (2016). How to Write a Literature Review Paper? Transport Reviews, 36(2). https://doi.org/10.1080/01441647.2015.1065456

Wentworth, D., \& Green, M. (2011). Learning to innovate. In $T$ and $D$ (Vol. 65, Issue 10). https://doi.org/10.1093/oso/9780190949501.003.0002

Wibawa, A. P. (2017). Paradigma Pendidikan Seni Di Era Globalisasi Berbasis Wacana. Dharmasmrti: Jurnal Ilmu Agama Dan Kebudayaan, 17(1). https://doi.org/10.32795/ds.v16io1.73 